\title{
The Anti-Sickling Properties of Medicinal Plants, Insights in Botanical Medicine ${ }^{*}$
}

\author{
Ioannis Krasias \\ Department of Health and Life Sciences, Biomedical Science, Coventry University, Coventry, UK \\ Email: ioanniskrasias@gmail.com
}

How to cite this paper: Krasias, I. (2021) The Anti-Sickling Properties of Medicinal Plants, Insights in Botanical Medicine. American Journal of Molecular Biology, 11, 165-189.

https://doi.org/10.4236/ajmb.2021.114013

Received: September 14, 2021

Accepted: October 26, 2021

Published: October 29, 2021

Copyright $\odot 2021$ by author(s) and Scientific Research Publishing Inc. This work is licensed under the Creative Commons Attribution International License (CC BY 4.0).

http://creativecommons.org/licenses/by/4.0/

\begin{abstract}
SCD is one of the most prevailing homogeneous inherited haemoglobinopathies causing a plethora of various clinical complications to the patients. The high mortality and morbidity severely concern the Western community, where numerous clinical trials and research for a cure are in process. In order to alleviate patients from the severe symptoms of the disease, avoiding the side effects, Botanical Medicine exhibits concrete evidence, as a gold candidate, to be the salvation to the problem. The Preferred Reporting Items for Systematic Review (PRISMA) protocol has been used to achieve extensive research on the topic, focusing on the identification and evaluation of the phytochemical properties of common medicinal plants. Meta-analysis has also been implemented on the results of published literature. Forest plots have been plotted, comparing and evaluating the results' validity and significance. The meta-analysis results have undoubtedly demonstrated the importance and significance of the medicinal plants and their properties against various clinical complications, focusing on the pathogenicity of SCD. Surprisingly, their effectiveness to suppress haemoglobin polymerisation and increase the $\mathrm{Fe}^{2+} / \mathrm{Fe}^{3+}$ ratio in patients, enhanced the normal morphological erythrocytes' appearance by suppressing the sickle shape of drepanocytes. Research made on the epidemiology of SCD associates the disease with the geographical frequency of malaria infection. Based on the natural selection theory of Charles Darwin, nature aids in the population's survival by the endemicity of various medicinal plants in areas with increased SCD patients. Limitations to the medicinal plants' consumptions and further therapeutic options have been discussed.
\end{abstract}

\section{Keywords}

"Anti-Sickling”, "Medicinal Plants", “Alternative Medicine”,

"Haemoglobinopathies", "Sickle Cell Anaemia ${ }^{\star} /$ Disease $e^{\star}$, "Clinical

Haematology", "Aloe Vera Extract", "Plant* Extract*" and "Sickle*/Cell"

*The paper has been completed as a dissertation project in BSc Biomedical Science course at the Coventry University. 


\section{Introduction}

Sickle cells disease (SCD) encompasses an extensive category of different haemoglobinopathies in which the patients inherit variation in their haemoglobin molecule, causing mutation and morphological alterations to the erythrocytes [1]. Sickle cell anaemia (SCA) is one of the major diseases within the cohort of haemoglobinopathies, characterised by the homozygote genotype referred to as haemoglobin-SS. The aforementioned disease state is caused by the mutation occurring at the sixth codon of the $\beta$-globin gene. This mutation arises from the replacement of the hydrophilic glutamic amino-acid with hydrophobic Valine. The mutation of the $\beta$-globin is related to miscellaneous genetic and environmental associations due to its alterable phenotypic expression and solidifies the sickle cell gene pleiotropic in nature [2]. These red blood cells (RBCs) encompass $\mathrm{HbS}$ molecules or a combination of abnormal $\beta$-alleles. When exposed to a deoxygenated environment, erythrocytes become rigid after the polymerisation of the haemoglobin molecules. Thus, the shape of the sickle erythrocytes originates from the distortion of the normal disc biconcave shape. Further fluctuations in different haemoglobin levels, and particularly in Foetal-Haemoglobin $(\mathrm{HbF})$, which by the age of 6-months documents a decrease, cause persistent clinical manifestations to the patient [3].

Patients with SCA exhibit symptoms with major severity. The irregular shape of the RBCs makes them liable to haemolysis, which is caused due to the half-life of sickle erythrocytes as well as further infections and leukocytosis [4]. The clinical manifestations are caused by RBCs' abnormal morphological characteristics, in which their flexibility is compromised, leading to blood circulation impairments and vaso-occlusion thereafter [5]. The other category of SCD is derived from a point mutation that replaces the glutamic amino acid to lysine in the globin chain resulting in $\mathrm{HbC}$. When $\mathrm{HbC}$ is combined with $\mathrm{HbS}$, then HbSC disease and RBCs' crystallisation occurs. The overall symptoms of HbSC differ from HbSS; however, the origin and ethnic background of the individuals suffering from sickle diseases have been acknowledged to alter the outcome and symptoms' severity [6].

Undoubtedly, SCD affects a number of citizens in the global population, causing life-threatening haematological disorders, ensuing in death in some instances [7]. The originated impediments of the disease are based solely on the sickle shape erythrocytes, which disrupt the normal physiology at both molecular and organ systemic level. Acute and chronic organ complications are the major concern of patients. The severity of these complications fluctuates among the different geographical areas and each individual's habitat [8]. The prevalence of the morbidity and the mortality rate of the disease have been monitored, and significant numbers have been documented in the area of sub-Saharan Africa. Approximately half-million children are the victims of this molecular abnormality of the erythrocytes annually. A large proportion of these infants are born into high tropical regions increasing the mortality rate critically [9]. Shedding new light on genetic background, Sri Lanka's studies have demonstrated that the ori- 
gin of the HbS occurrence depends on the migration wave from different topographical regions. This statement validates that the different backgrounds of each individual can determine the severity and prevalence of the disease occurrence [10]. Thus, screening programs have a vital role in the detection of the disease in early stages and the trait existence, used as a preventative measure against the disease inheritance [11].

Known to affect every organ of the human body, SCD is a principle challenge of the healthcare community, as it can cause an end-organ dysfunction altering the physiological properties of the brain. Neurological complications, such as cerebral sinus thrombosis and haemorrhagic stroke, among others, are the commonest symptoms leading to death [12]. The morphological appearance of the mutated erythrocytes due to the sickle cell gene presence can have tremendous health complications. Stroke like symptoms are documented in a wide range of studies in paediatric haematology departments of hospitals, diagnosing children under the age of five with silent cerebral infracts [13]. In general, infarctions are amongst the commonest complications caused due to the shape of the drepanocytes leading to a decrease or absence of the cerebral circulation and subsequently to neurons cellular injury [14]. Symptoms such as seizures can likewise be caused by epilepsy syndrome, altering the level of the patient's consciousness and stroke presentation [15].

A more holistic and alternative treatment based on Botanical Medicine (BM) is pivotal in order to improve the life expectancy and quality of the patients suffering from SCD symptoms [16]. The success in controlling numerous diseases due to the use of medicinal plants has been vigorously reported in evolving countries. Indisputably, SCD could not be excluded. Various cross-sectional studies which are focusing on the therapeutic effects of alternative medical care illustrated concrete clinical evidence. The humans' immunity by the use of medicinal plants exhibited an advantage over traditional treatment in an assembly of individuals regardless of their cultural affiliation [17]. Notably, a large proportion of the world's population relies on the benefits of BM as their primary form of health care. The antisickling perspective of various medicinal plants illustrated an increase in the gelling time of drepanocytes [18]. Studies in vivo and in vitro, with medicinal plants, endemic in Nigeria and sub-Saharan Africa, displayed that distinct parts of the plant could be used to extract numerous phytochemical agents assisting the anti-sickling potential on RBCs. Specifically, Aloe Vera has been reported for its property to upsurge the gelling time of drepanocytes and converse the sickling-effect, diminishing episodes of vaso-occlusion and pain crisis. The antioxidant and anti-sickling properties of Dennettia tripetala and Physalis angulata have been delineated to stabilise RBCs' membrane, preventing sickle haemoglobin polymerisation [19].

Known from their illustrious history, medicinal plants have been widely used as medical remedies since they possess therapeutic properties. Different studies and clinical trials experimented with their most essential constituents, which are substitutes for different therapeutic purposes [20]. Medicinal plants aided in 
various medications' development that have been used successfully for multiple diseases. At the sickle genetic level, the HbS polymerisation stage and RBCs' membrane threshold are targeted for alterations in anti-sickling level [21]. The phenomenal and astonishing health benefits of Aloe Vera for its antioxidant activity have been systematically reported by Langmead et al., presenting that the plants' extract aids to preserve the membrane's integrity and assisting its antioxidant properties [22]. Further experiments found that metalloproteinase inhibitors contributed to the anti-tumoural properties having anti-angiogenic abilities [23]. Characterised as miraculous plants, their properties have been evaluated for their effectiveness in reversing drepanocytes back to biconcave shape and protecting from secondary infections contributing to RBCs' pathogenesis.

\section{Aims of the Study}

This systematic review aims to study and evaluate the recent published literature on Botanical Medicine, targeting the antisickling properties of medicinal plants. The plants' eligibility is based on their phytochemical compounds' composition, reversing drepanocytes back to biconcave shape of the RBCs. This is achieved by the regression of the pathological side effects and the clinical manifestations presented by the patients. Further appraisal of the toxicological effects on the extracts' consumption aid in the exhibition of possible limitations and alternative treatment options.

\section{Methodology}

Comprehensive systematic research has been performed using different validated databases in order to concentrate all the necessary information for an inclusive review on the topic. The research methodology and strategy for information extraction have been done using the Preferred Reporting Items for Systematic Review, PRISMA [24]. Additionally, a meta-analysis has been performed in order to appraise the association between the different clinical trial studies, reviewing their limitations and achievements [25]. Published literature has mainly been obtained through PubMed and ScienceDirect, amongst other databases. Through thorough research on a wide range of published papers, it has been observed that numerous clinical trials focused on in vivo and in vitro research and not on animals. This study will evaluate the effectiveness of the medicinal plants in vitro. The selection criteria and the data extraction from the research are demonstrated below.

\subsection{Inclusion Criteria}

1) Studies that have been focused on investigating whether the application of a wide range of medicinal plants' extract or different product extracted or derived from those plant will suppress the sickle appearance of the RBCs. To achieve that, clinical trials that aid in the direct or indirect administration of the product to the patients' samples have been considered.

2) The trial studies must demonstrate or mention that they have analysed and 
examined the blood samples before and after the treatment. This analysis helps identify the differences and the potential changes due to each step of the procedure.

3) Undoubtedly, the extraction process plays a pivotal role in the collection of the desirable constituents of the plants' samples. Any damage or distraction will have an apparent effect on the present of desirable constituents and the outcome. It is recommended to analyse results from studies that they have already been validated for their methodology, and their results are conclusive.

4) When the RBCs are getting into the sickle appearance, their properties and functions are altered, respectively. Evaluation of those actions is vital for patient survival to conclude whether the treatment is effective for the wide population and the apparent side effects that they might cause.

5) Inclusion of studies targeting the analysis of the RBCs' apoptotic rate using different methodologies and recommendations. Apoptotic detection, Osmotic fragility for haemolysis, Catalase and antioxidant activity methods' evaluation and clinical/laboratory trials are recommended for the study. However, not all papers must include this criterion.

\subsection{Exclusion Criteria}

1) All studies without readily available results or methodology of getting the results have been rejected or withdrawn.

2) No studies with clinical trials on animals have been considered and are excluded from the study's meta-analysis.

3) Although the current study focuses on medicinal plant properties, results regarding other medical or drugs methodologies have been used for background purposes and critical comparison only.

4) No review papers, or seminars, or drafts have been accepted. Studies must be primary research, medical trials or laboratory work.

5) Clinical trials with pending or published results more than fifteen years ago have been automatically rejected for critical appraisal. Studies that took place or published before the fifteen-year window have been taken under consideration for background information and discussion only.

\subsection{PRISMA and Scoping Research}

Completing the first scoping research in the different databases, (234) published papers have been found and saved for further analysis by the PRISMA method. EBSCO (Elton B. Stephens Company) platform was selected to be used for research in scientific academic literature appropriate for the level of a systematic review. From (234) papers in the EBSCO platform, (123) derived from PubMed, (12) from Medline, (96) from ScienceDirect and (3) from ResearchGate databases. Scoping research aimed to identify the available literature on the topic using keywords, such as "anti-sickling", "medicinal plants", "alternative medicine", "haemoglobinopathies", "sickle cell anaemia ${ }^{\star} /$ disease $^{\star}$ ", "clinical haematology",

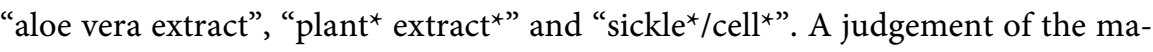
terial followed and exclusion criteria were applied. From (234) papers, $(\mathrm{n}=17)$ 
have been excluded as the methodology was not available, $(\mathrm{n}=129)$ studies on animals have been rejected and $(n=61)$ papers which were published out of the recommended window and reviews were excluded from the study. The final number of papers after the selection was $(n=27)$.

${ }^{*}$ An algorithmic demonstration of PRISMA method illustrated in section 2.5 .

\subsection{Critical Appraisal Skills Programme Checklist (Adapted from; https://casp-uk.net/casp-tools-checklists/)}

An additional alternative stage of the procedure includes applying of a critical appraisal skills programme checklist to assess whether the studies found were methodologically sound and fulfilled the inclusion and exclusion criteria mentioned above [26]. After selecting the appropriate papers, a large proportion of them have been used for the introduction part as they had factual background information essential for understanding the topic. Six of them have fully covered the inclusion criteria and were appropriate for critical evaluation and discussion. These papers are illustrated clearly in Section 2.6 and have been critically appraised for their outcomes in the discussion section.

\subsection{Preferred Reporting Items for Systematic Review, Algorithm}

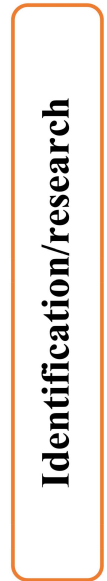

Records identified through databases searching for relevant material

$$
\mathrm{N}=234
$$

Medline, $\mathrm{n}=12$

ResearchGate, $\mathrm{n}=3$

Screening for duplicates: no duplicate papers found $n=234$

Screening for full text documents: all papers that have been downloaded, had full text available.

No purchase or rental was necessary

ScienceDirect, $\mathrm{n}=96$ 


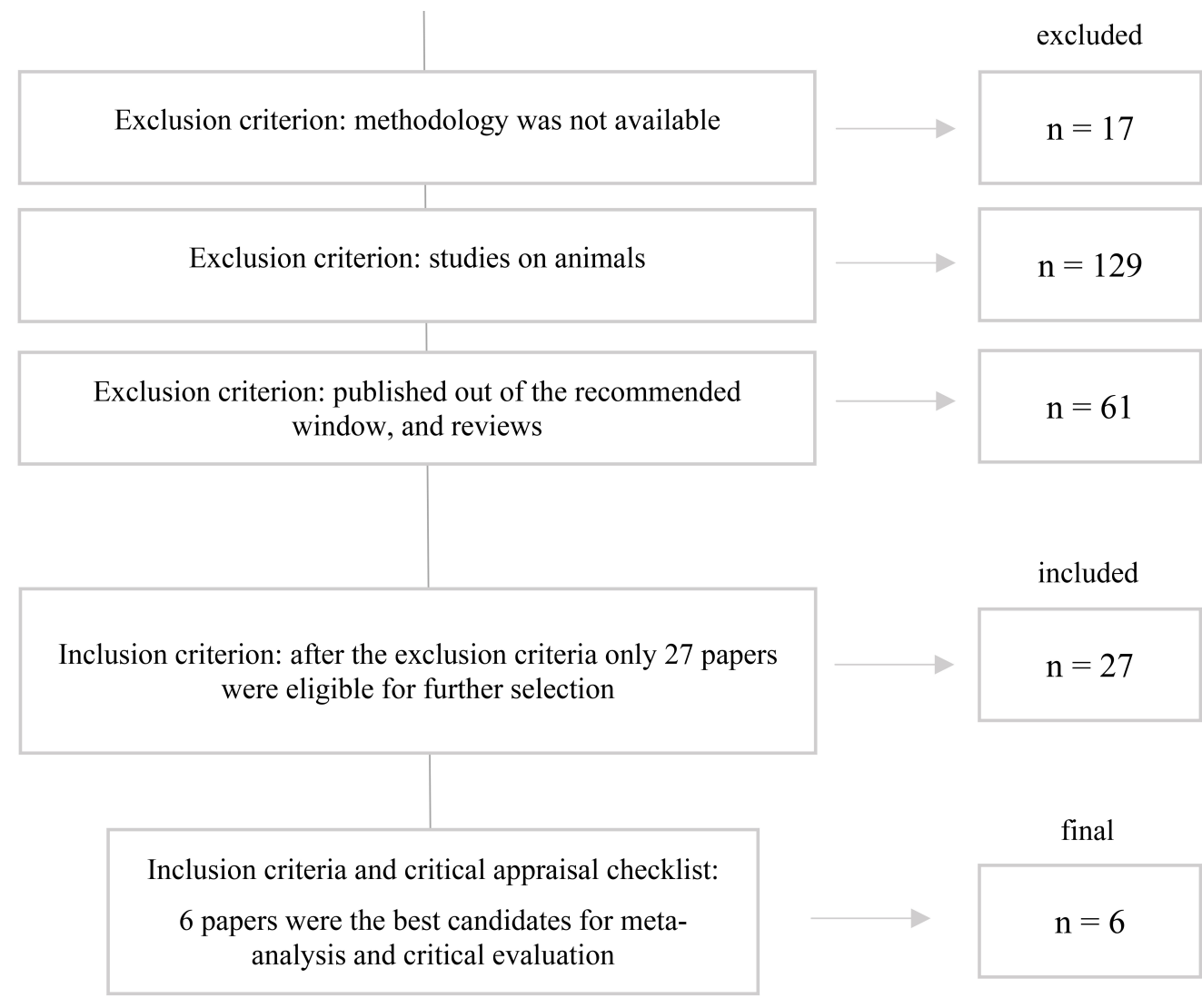

\subsection{Final List of Papers Selected for Critical Evaluation and Meta-Analysis}

1) "The effect of Aloe vera plant (Aloe barbadensis) extracts on sickle cell blood (HbSS)"

Authors: Nwaoguikpe R.N., Braide, W. and Ezejiofor, T.I.N. (2010)

Medicinal plants under investigation: 1) Aloe Vera

2) "In vitro antisickling effects of Xylopia aethiopica and Monodora myristica"

Authors: Uwakwe A.A., and Nwaoguikpe R.N. (2008)

Medicinal plants under investigation: 1) Xylopia aethiopica and 2) Monodora myristica

3) "The antisickling potential of four Curcubits (T. Occidentalis, C. maxima, C. lonatus and C. sativus)"

Authors: Nwaoguikpe R.N., Ujowundu, C.O and Okwu G.N. (2013)

Medicinal plants under investigation: 1) Telferia occidentalis, 2) Citrullus lonatus, 3) Curcubit maxima, 4) Curcumis sativus

4) "Bioassay-guided isolation and partial characterization of an antisickling compound from Enantia chlorantha"

Authors: Ejele, A.E., Akpan, I.O., Ogukwe, C.E., Onyeocha, V.O., Ukiwe, L.N. (2012)

Medicinal plants under investigation: 1) Enantia chlorantha

5) "Anti-sickling properties of aqueous extracts of dennettia tripetala and 


\section{physalis angulata"}

Authors: B.M. Onyegeme-Okerenta, E.B. Essien and J.I. Esin. (2019)

Medicinal plants under investigation: 1) Dennettia tripetala and 2) Physalis angulata

6) "Anti-Sickle erythrocytes haemolysis properties and inhibitory effect of anthocyanins extract of Trema orientalis (Ulmaceae) on the aggregation of human deoxyhemoglobin $\mathrm{S}$ in vivo"

Authors: P.T. Mpiana, K.N. Ngbolua, V. Mudogo, D.S.T. Tshibangu, E.K. Atibu, D.D. Tshilanda and N.M. Misengabu (2011)

Medicinal plants under investigation: 1) Trema orientalis (Ulmaceae)

*(fully referenced in reference list)

\section{Results}

A statistical appraisal and meta-analysis have been performed in order to synthesize the results from the papers selected for further critical consideration. The figures and tables are presented in the graphs and figures of this systematic review have been performed using meta-analysis tools such as excel sheets and RevMan software, aiding in the plotting of forest plot diagrams and Chi-square tests. The purpose of the meta-analysis is the evaluation of the current use of medicinal plants as an alternative treatment option for individuals suffering from SCD. Various therapeutic strategies are currently under clinical trials in order to be acceptable candidates to treat the symptoms and reverse the sickling effect of drepanocytes. Numerous phytochemicals, amino acids, specific desirable components of the plants and the time of antisickling effectiveness are pivotal against the pathophysiology progression in various diseases and side effects caused by the sickle cells' morphology. All the studies have used control samples requiring treatment in triplicates minimizing plausible errors in the outcome. The standard deviation (SD) and the confidence interval (CI) 95\% were calculated in excel spreadsheets and found to be \pm 0.1 and 0.113 , respectively.

\subsection{Qualitative and Quantitative Presence of Phytochemicals, (Table 1)}

The presence of phytochemicals was the main focal point in various studies examining quantitatively and qualitatively, the phytochemical presentation in the plant extracts under investigation. Table 1 clearly shows that the majority of the

Table 1. Qualitative screening of phytochemicals, $(\times)$ presence of the compound.

\begin{tabular}{|c|c|c|c|c|c|c|c|}
\hline Sample & Tannins & Saponins & Anthraquinones & Phenols & Alkaloids & Flavonoids & Anthocyanin \\
\hline Aloe vera (Nwaoguikpe et al. 2010) & $\times$ & $\times$ & $x$ & $x$ & $\times$ & $\times$ & \\
\hline T. occidentalis (Nwaoguikpe et al. 2013) & $\times$ & $\times$ & & $\times$ & $\times$ & $\times$ & \\
\hline C. lonatus (Nwaoguikpe et al. 2013) & $\times$ & $\times$ & & $\times$ & $\times$ & $\times$ & \\
\hline C. sativus (Nwaoguikpe et al. 2013) & $\times$ & $\times$ & & $\times$ & $x$ & $\times$ & \\
\hline C. maxima (Nwaoguikpe et al. 2013) & $\times$ & $\times$ & & $x$ & $\times$ & $\times$ & \\
\hline T. orientalis (Mpiana et al. 2011) & $x$ & $x$ & & $\times$ & $\times$ & $\times$ & $\times$ \\
\hline
\end{tabular}


plant extracts are contain common phytochemicals such as tannins, saponins, phenols, alkaloids, and flavonoids. However, other studies have documented the presence of distinct components of the plant species such as anthraquinones and anthocyanins found in Aloe vera [21] and Trema orientalis plants [27], respectively.

\subsection{Variability in Vitamin C Concentration, (Figure 1)}

Variability in vitamin $\mathrm{C}$ concentration has also been shown in the results of different clinical trials, highlighting its effectiveness as an essential antioxidant aiding in antisickling potency and preventing clinical manifestations such as vaso-occlusion. Citrullus lonatus found to have an abundance of vitamin $\mathrm{C}$ in the plants examined, followed by Aloe vera, which present around the same concentration in both its leaf and gel component. Curcubit maxima and Telferia occidentalis did not show significant amounts of vitamin $\mathrm{C}$ in their extracts, which might indicate them as not such antagonistic and eligible candidates for the treatment.

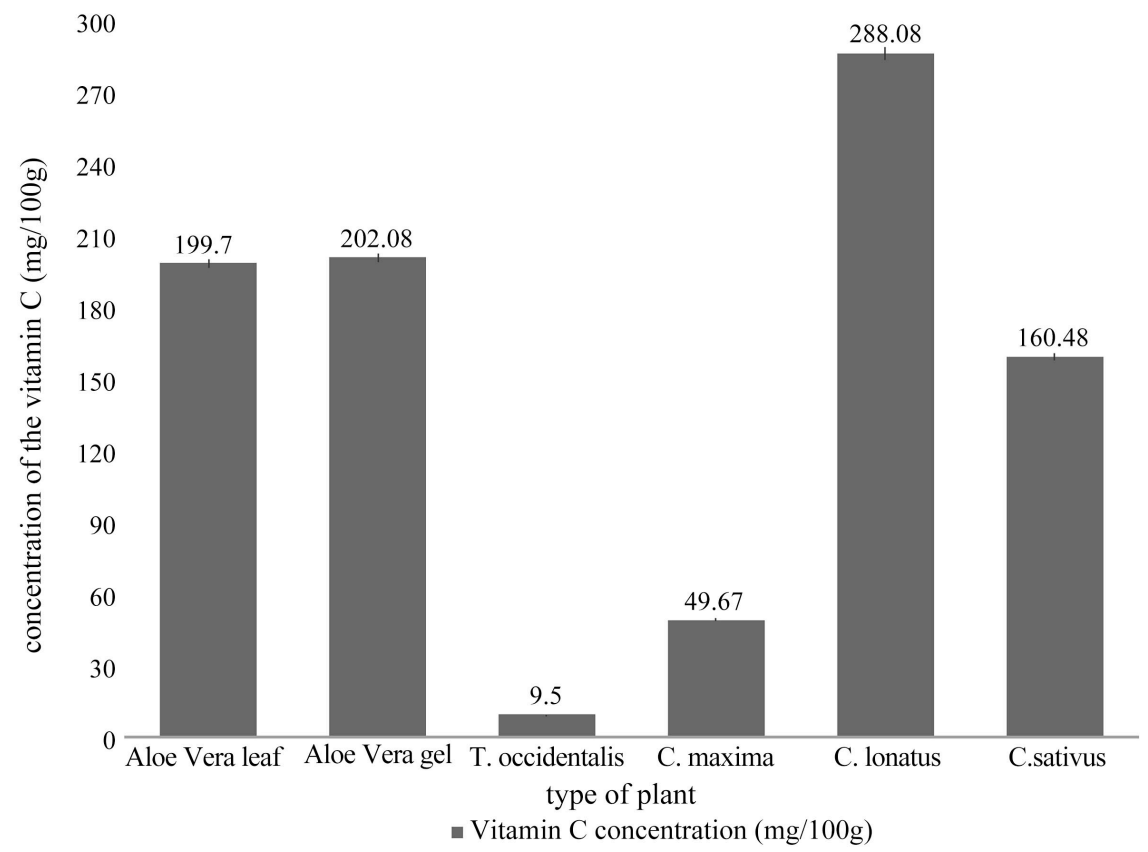

Figure 1. Variation in vitamin C concentration of medicinal plants' extract.

\subsection{Amino Acids Concentration in Medicinal Plants' Extra,} (Figure 2)

Having an essential role in the antisickling effect, plentiful amino acids have been detected in medicinal plants. Their concentration and heterogeneity of those extract in amino acids vary among the species of the plants greatly. Documentations of the potential concentration of amino acids showed that Aloe vera species and Citrullus lonatus have a higher concentration than other plants. However, the heterogeneity in both concentration and presentation of amino acids might alter the potential anti-sickling effect. 


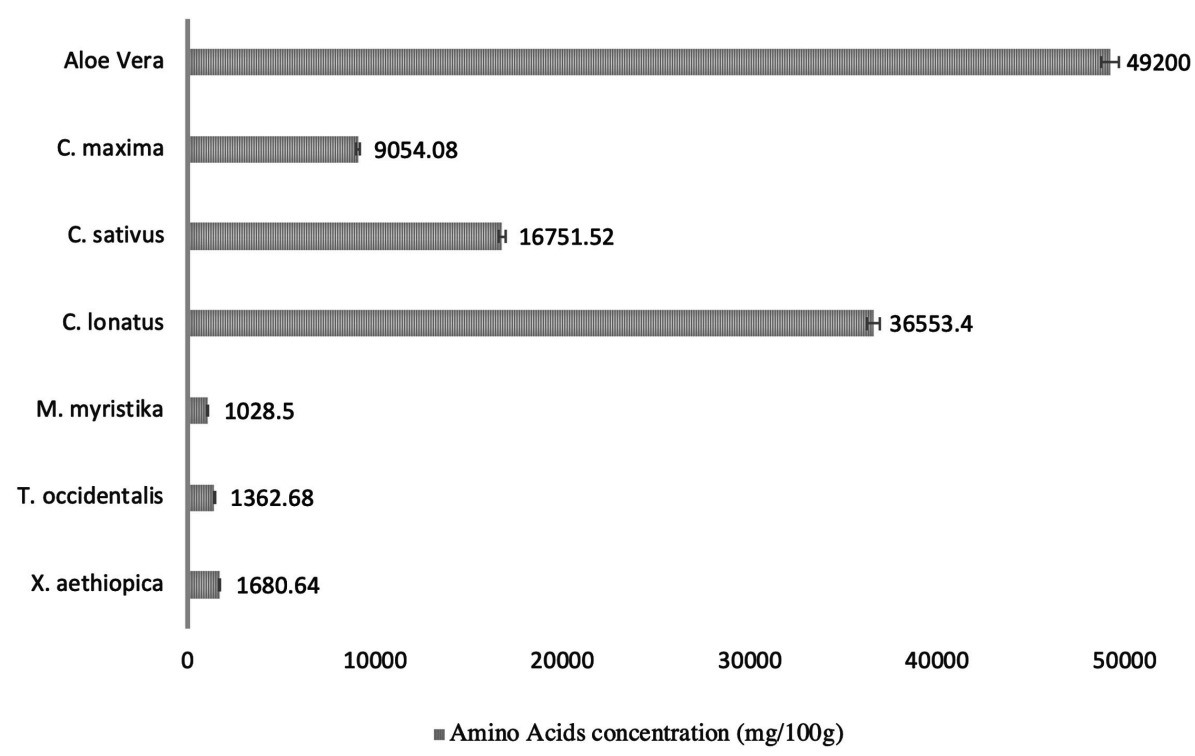

Figure 2. Amino acids concentration in medicinal plants' extract.

\subsection{Meta-Analysis of Ferric and Ferrous Iron Ratio Increase, (Figure 3)}

Clinical heterogeneity has been found in the studies presented in Figure 3, as different clinical variables has been used during these experiments. Extraction of seven different plants have been used for its effect on the Ferric and Ferrous iron ratio $\left(\mathrm{Fe}^{2+} / \mathrm{Fe}^{3+}\right)$ increased in patients with and without SCD. The outcome of the results is solely based on the plants' effectiveness, the procedure followed for the extraction, and the nature of the extract. Subjective assessment of heterogeneity in the extract's effectiveness is seen in the graphical part of the forest plot, illustrating a variability in the increase of the iron ratio. Telferia occidentalis extract increased the iron ratio the most, compared to the other plant extracts, favouring the treatment of the patients the most. In the contrary, Curcubit maxima was not much effective as the increase documented was insignificant.

\subsection{HbS Polymerization Inhibition, (Figure 4)}

Presentation of subgroup analysis is documented in Figure 4, illustrating the polymerisation inhibition of $\mathrm{Hb}$ molecules in the sample of patients with SCD after the treatment of a particular medicinal plant extract. The highest clinical intervention was shown in the study of Nwaoguikpe et al. (2013), examining the effectiveness of the four Curcubits. Their results document a polymerisation inhibition from $94.58 \%$ to $97.08 \%$, ranking these plants as the most efficient in the studies investigated. The overall mean value of Hb's inhibition polymerisation from all studies is $91.54 \%$ indicating that the studies documented similar outcomes in their results. A Chi-square test has been performed examining the presence of heterogeneity amongst the studies. The p-value of the Chi-square test was 0.361216 ( $p>0.05)$, classifying the results as significant. The test statistic 
value has also been calculated (7.68) and shown to be lower than the experiments' critical value (14.06). Thus, the null hypothesis $\left(\mathrm{H}_{0}\right)$ is not rejected as there is no evidence of a difference in the polymerisation inhibition expected (100\%) to polymerisation inhibition observed by the experiments.

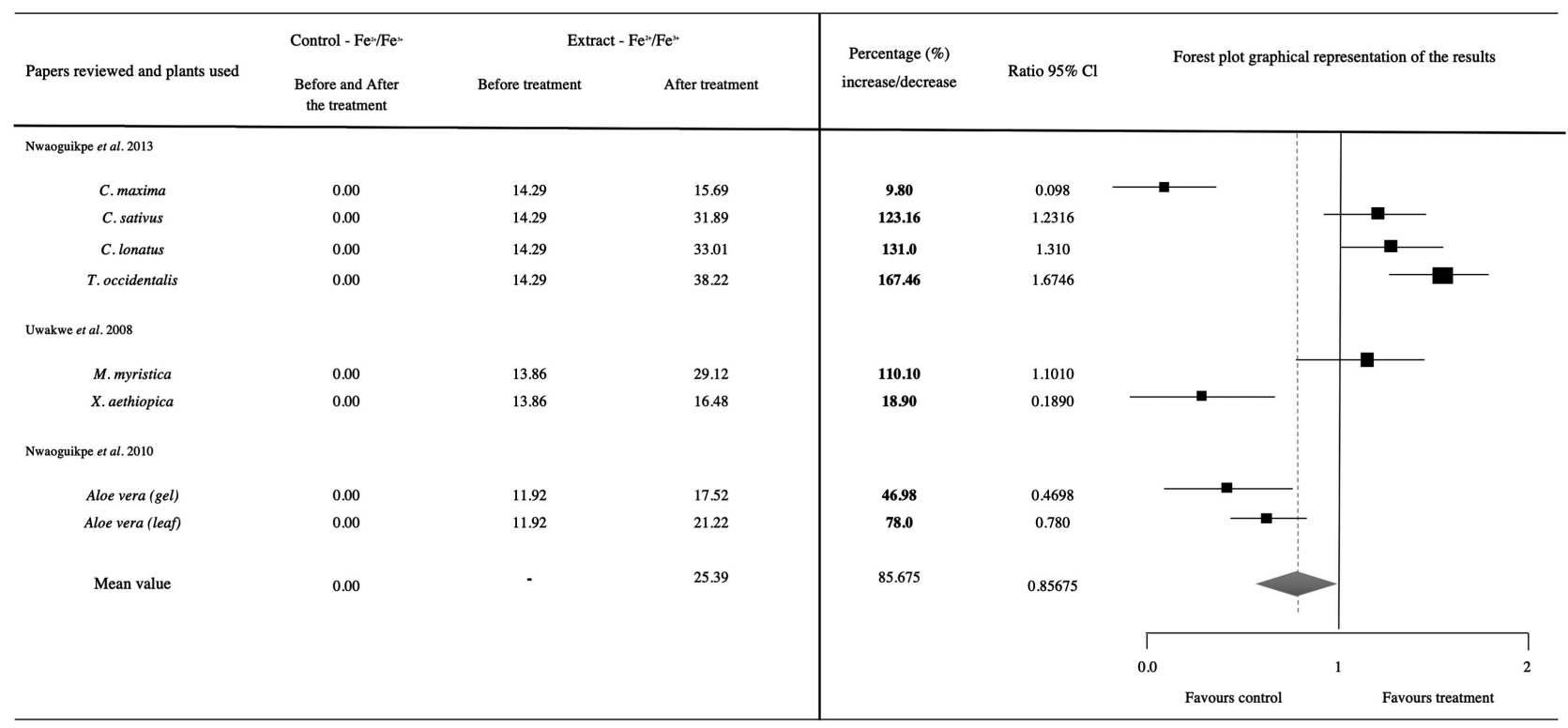

Figure 3. Forest plot meta-analysis of ferric and ferrous iron ratio $\mathrm{Fe}^{2+} / \mathrm{Fe}^{3+}$ increase. Numerical and graphical representation. SD: \pm 0.1 . All the samples were used and analysed in triplicates (thus, $\mathrm{n}=3$ ). Cl (Confidence Interval) $95 \%=0.113$ which is (mean \pm $0.113)$ this appears as the lines of each square.

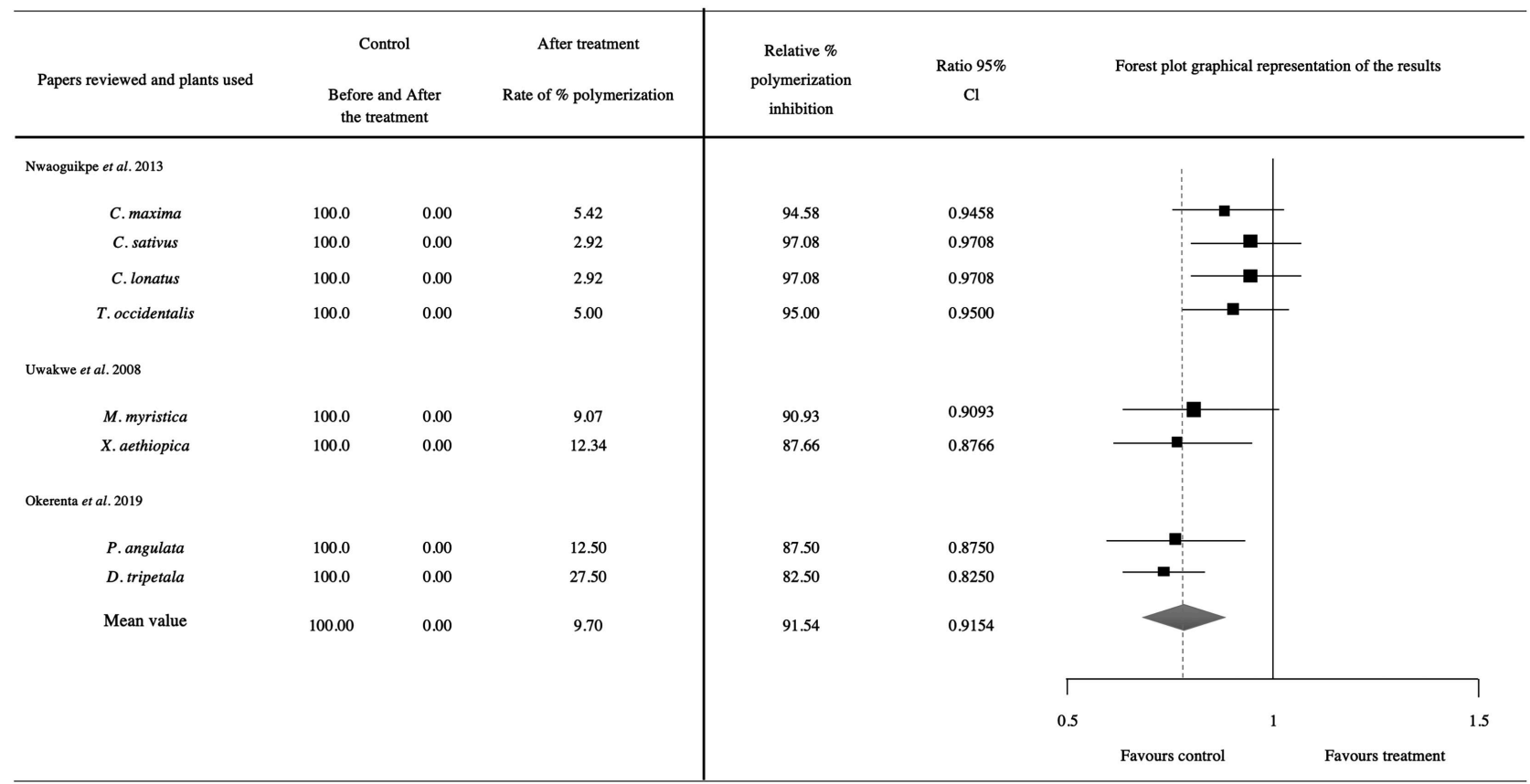

Figure 4. Forest plot meta-analysis of HbS polymerization inhibition. Numerical and graphical representation. SD: \pm 0.1 . All the samples were used and analysed in triplicates (thus, $\mathrm{n}=3$ ). $\mathrm{Cl}$ (Confidence Interval) $95 \%=0.113$ which is (mean \pm 0.113 ) this appears as the lines of each square. Chi square test provides value of 0.361216 , indicating no heterogeneity in the studies. 


\subsection{Testing of the Studies in Systematic Review for Published Bias}

Published bias has been predicted to be low in the studies used for this systematic review. Although it is difficult to estimate the percentage bias of the studies, readers' opinion of the research can be altered by the exclusive presentation of positive results. The studies under investigation for their effectiveness in antisickling properties of the medicinal plants have shown both positive and negative results in the majority of the areas of concern, shown to have a minimum bias. In Figure 2, three out of seven extracts tested for amino acids concentration were significantly low, favouring the control instead of the treatment. Similar results have been obtained in Figure 1, where T. occidentalis and C. maxima presented significantly low amounts of vitamin $\mathrm{C}$ than other extracts. Controversial results are shown in Figure 3, where half of the plants tested for iron ratio favour the treatment instead of the control. Although it is difficult to predict the bias likelihood of a published paper, the majority present an odds ratio higher than one, which is an indicator of bias [28].

\section{Discussion}

Raising global awareness, SCD has extensively been observed and studied by numerous research groups, categorising it as one of the most severe genetic inherited conditions, threatening individuals from distinct parts of the world [29]. The major concern documented periodically in the Western literature of the past decades focuses on the rheology affliction of the RBCs due to haemoglobin genetic alterations [30]. Such modifications amend the normal blood physiology leading to severe chronic clinical complications, increasing the mortality rate if it remains untreated [31]. The allele heterogeneity disruption amongst the broad population derived from various aetiological causes, cumulates the homogeneous frequencies of the mutated haemoglobin in affected individuals [32]. The prevalence of the diseases seems to fluctuate over the years, emerging patients' clinical attention, and further research in the era of therapeutic advancements [33] clinical studies from the underdeveloped countries and high-burden communities on patients' cases showed that the commonest pathological variant of haemoglobin, $\mathrm{HbS}$ allele, with a frequency estimated to be $15 \%$ over the remaining haemoglobin variants [34]. The diverse factors which contribute to the epidemiological transition of SCD are highly important. Lack of standard public health provision and the diminished nutritional improvements in low-burden communities associated with the lack of educational background and healthcare settings enhance the number of sickle cell cases [35]. Confounding evidence related to the $\mathrm{HbS}$ allele's frequencies suggest that the poor discrimination amongst the indigenous and migrated population, which is starring in the community, is the main responsible socio-economic factor [36]. Thus, the increase of the gene incident leads to the disease's hampered management and the uncontrollable mortality rate. A solution to eradicating the disease's incidence was found to be 
the migration of the heterozygote population of $\mathrm{HbS}$ to other geographical areas avoiding intra-population reproduction [37].

The epidemiological profiles of haemoglobinopathies, particularly of $\mathrm{HbS} \mathrm{mu}-$ tations, illustrate an association of the disease to other microbial-related infections, such as Malaria form the Plasmodium falciparum parasite, threatening the extinction of humankind [38]. Reports on the geodatabase of HbS allele prevalence acknowledged the pivotal role of natural selection theory which is determined by the presence of the alleles in areas with high endemicity of the bacterium, endangering individuals' survivor after their exposure to it [39]. Several hypotheses on the topic have been documented, focusing on the natural selection theory suggested by Charles Darwin. These theories support the adaption of human entities to microbial enemies, related to the geographical distribution of the mutated haemoglobin alleles [40]. Epidemiological reports from various studies have been focused on the relation between the Plasmodium falciparum parasite and the SCD's epidemiology [41]. Despite the overwhelming epidemiological sector of SCD due to the malaria existence, the study of Wambua et al. investigated the importance of the major haemoglobinopathies to the protection against the complications of the parasite infection. Their findings suggest a reverse effect of anaemia-related symptoms caused by the infectious bacterium [42].

Since malaria is acknowledged as a significant public health concern, affecting individuals who have had close contact with the particular bacterium and got infected by its presence. An obstacle against malaria infection is the bacterium's genetic diversity contributing to asymptomatic carriers and the transmission to unsuspected individuals [43]. Studies in Ghana and Cape Town showed that seasonal variation of the bacterium alleles could alter the transmission and malaria infection [44]. Cameroon, amongst other countries, has investigated the malaria transmission dynamics and their apparent effect on the HbS allele distribution [45]. Similar reports from Columbia stated that parasite infection establishes malaria and is strongly related to the SCD endemicity in areas of the aforementioned infections [46].

In their findings, Penman et al. recommended a link between the global distribution of malaria infection and the existence of the mutated haemoglobin alleles in the population [47]. Thus, the heterozygote advantage of HbS is derived from the natural reinforcement by the individuals' habitat in areas with a high risk of malaria infection. However, this can turn into a fatal disadvantage as intra-population reproduction of heterozygote individuals increases the risk of homozygote to the HbS allele births [48]. This geostatistical model, is based on the allele variation and the incidence of the disease due to the environmental conditions of the population habitat. Further multisectoral interventions are restricted due to the limited understanding of the SCD epidemiology [49].

Recent studies have investigated and documented the relationship between the Foetal haemoglobin $(\mathrm{HbF})$ and the severity of the SCD clinical manifesta- 
tions. The group of Adeodu et al., in their experimental cross-sectional study, which was based on the quantification of the HbF molecules, demonstrated that a dropped concentration of $\mathrm{HbF}$ was related to the severity of the symptoms' presentation. Since $\mathrm{HbF}$ molecules are responsible for the compensation of oxygen distribution to the body, its absence or deficiency leads to clinical alterations [50]. Thus, an early quantification of the $\mathrm{HbF}$ will reduce the mortality rate, which is compromised by acute chest syndrome and stroke presentation, especially in children [51]. Further studies have focused on the individual's pedigree and extracted concrete evidence that SCD is highly related to the population of people who had ancestors from the areas with increased disease endemicity. Populations migrated to Germany and France exhibited a high risk of SCD pathogenesis, as the majority of their roots came from the sub-Saharan Africa [52]. Gender can also alter the disease pathogenesis as more severe clinical manifestations are presented in males, as the influence of the disease is lower in females. The hormonal variation amongst the genders is the main responsible factor [53]. Although the exact reason is still elucidated, growth failure in children observed in African population is associated with haemolysis and microalbuminuria [54].

Surprisingly, the endemicity of medicinal plants has extensively been reported in areas with high rate of malaria infection, contributing to the SCD occurrence [55]. An association of the antisickling properties of those plants, and their endemicity, might not be just a coincidence [56]. As Darwinian theory of species' selection, focuses on survival, the mechanism of nature to protect humans against the fatal consequences of SCD, has an apparent result of the plants endemic to those areas [57]. Whilst SCD causes a pitfall and exhaustion of the patients; further therapeutic approaches seemed to be applied as a solution to the problem. Numerous drugs, such as hydroxyurea; increasing $\mathrm{HbF}$ affinity, were shown to be successful in treatment and symptoms mitigation [58]. However, limitations and side effects decrease their effectiveness and make them less-harmless for consumption and application proposes [59]. Solutions to the problem have been tracked from ancient times, where the astonishing properties of medicinal plants heightened the importance of Botanical Medicine [60]. Their antisickling abilities have considerably been evaluated, alleviating symptoms-related to SCD and malaria infections [61].

Published literature for botanical medicine have dedicated and recognised the properties of the most common medicinal plants. However, many studies support the theory that these plants are found in higher numbers, in endemic areas. The evolution of exchange and travelling around the globe aid in the spread of the plants worldwide [62]. Concrete evidence of extensive literature reviews and clinical trials recommended investigation of the biochemical constituents of the plants for further understanding of their pharmacological mechanisms [63]. Similar antisickling activity reports used in this systematic review evaluate the effectiveness and capabilities of future candidates for treatment options [64]. A variety of traditional healer plants studied so far manifested alleviation of nu- 
merous clinical symptoms exhibited in patients. Thus, botanical medicine has been recognised for its contribution to anti-sickling and anaemia prohibition properties [65].

From the studies evaluated for their results efficacy and the anti-sickling effectiveness of the medicinal plants, satisfactory results have been observed. A mean value of $91.54 \%$ polymerisation inhibition resulted from the forest plot analysis of eight medicinal plants presented in Figure 4 from three different studies ([18] [19] [66]). The importance of the phenomenon's prohibition derived from the clinical manifestations caused by the formation of $\mathrm{HbS}$ fibres after delivering oxygen to the peripheral tissues [67]. Then, the erythrocytes transformed into a sickle shape after the protein conversion to fibres molecules due to the negligible free energy barrier being released. Hence, cells release water molecules surround the HbS polymer. These metastable water droplets alter the fibre nucleation kinetics, leading to the disease occurrence and morphological changes to the erythrocytes' membranes [68]. Therefore, the aforementioned procedure is disparaged, causing less clinical severe manifestations to the patient as the sickle morphology is diminished by the polymerisation inhibition of $\mathrm{HbS}$ molecules [69].

The presence of various amino acids in the plant extracts aid in HbSS polymerisation inhibition improvement [70], possessing in vivo properties and increasing the gelling time of drepanocytes as documented in clinical studies of several plants and fruits [71]. Other phytochemicals presentation has an essential role in their therapeutic properties. Phytochemicals such as alkaloids, ketones, flavonoids, phenols, tannins, and saponins control the inflammatory responses during infection, stimulating the formation of immune cells and inducing blood cells proliferation and further differentiation [72]. Flavonoids and alkaloids are well known for their therapeutic properties against symptoms related to pain. Their presence in the plants leaf extract will help relieve the chronic pain caused by vaso-occlusion [73] and stroke-related symptoms leading to vascular-crisis [74]. Flavonoids also have beneficial action for the physiological function of the gastrointestinal system, especially the intestines' peristaltic movements as well as the treatment of haemorrhoids [75]. Phytochemicals like tannins exhibited clinical effectiveness in children with diarrhoea by favouring the rapid recovery of the intestines' epithelial mucosa [76]. Necessary for its antispasmodic and sedative actions, the heterogeneity of phytochemicals is significant, as it covers a range of side complications of the disease.

Despite the importance of the previously discussed plants, the uncontrollable administration to patients causes a toxicity risks unaccompanied by various health complications and lead to farther clinical manifestations [77]. An example of persistent mutagenic and carcinogenic compounds produced by a variety of medicinal plants is a type of alkaloids known as pyrrolizidine. The persistent plant toxins presentation in water which is used by plants, increased the microbial and anthropogenic chemical pollution, threatening the patients [78]. A mul- 
tidisciplinary study that focuses on the safe consumption of medicinal plants is concerned with the potential risks to pregnant women and high-risk patients. Risks such as embryotoxicity induced by a teratogenic activity lead to abortifacient effects. In their study review Bernstein et al., recommended the avoidance of the plants discussed previously [79]. Plants from the Occidentalis family and Aloe vera, when administered orally, are cause laxative potential, which leads to uterus contraction and abortion [80]. More serious complications have been documented by the high dose and perinatal exposure of Occidentalis plants leading to foetal death, mother's tissue damage and myocardium necrosis [81]. The daily burden of consumers has been published by Drabek et al., reporting the presence of heavy metals in supplements produced by terrestrial plants and microalgae. Elements such as cadmium, lead, and cold mercury contribute to adverse side effects and health complications, related to the prolonged time of exposure [82].

On the contrary, recent studies on the ongoing SARS-CoV-2 virus pandemic investigated medicinal plants' inhibitors against the virus clinical complications. The presence of antiviral proteases such as Croxin and Digitoxigenin aid in molecular docking [83]. The anti-inflammatory and antiviral activity of those plants against common human viruses reported in South India, soothing and relieving possible symptoms and protecting against contamination and infection [84]. Apart from the antiviral and anti-inflammatory properties of the plants, anticancer activity by the metalloproteinase inhibitors from their extracts has been documented in various studies to inhibit the metalloproteinase- 9 commonly found in chronic and cancer wound [85]. Aloe vera was used as a model plant for the demonstration of its extract capacity to inhibit metalloproteinase-2 from colorectal cancer patients. Preventing metastatic cancer cells migration and antiangiogenic capacity, Aloe vera species are now considered by the pharmacological industry as a gold candidate for cancer treatments [23].

\section{Conclusion}

Considering the complicated endemicity and the various factors contributing to sickle cell disease, the causes of the severity of the clinical manifestations are still pending. This systematic literature review aims to concentrate on the multisectoral aspects of the disease occurrence and the evaluation of alternative treatment options based on the principles of the Botanical Medicine. A plethora of disease management strategies has been proposed by numerous clinical trials. However, limitations and risk factors should be taken under serious consideration in order to comprehend the action of the medicinal plants. The tendency of red blood cells and their shape transformation to drepanocytes should be the main focus of further studies, as it remains the primary reason for the clinical manifestations and disease severity. Understanding the causes and investigating treatment options for the disease will lead to a decrease in both the mortality and morbidity rate of the affected individuals. 


\section{Acknowledgements}

This systematic review paper and the research supporting it would not have been achieved without the exceptional support of my supervisor, Mrs. Yvonne Elliott. Her enthusiasm and motivation have been an inspiration and kept my work on track from my first encounter with the proposal to the countless drafts of the portfolio, and thankfully for her comments on an earlier version of the manuscript. I am also immensely grateful to Dr. Lauren Acton, as a module leader, for her precious help during the first stages of the research and the guidelines she shared aiding me to reach my full potential. However, any errors are my own and should not tarnish the reputations of the esteemed persons. I would also like to express my gratitude to the Faculty of Health and Life Sciences and the Academic Writing Department of Coventry University for sharing their pearls of wisdom during the course of this research.

\section{Copyright ${ }^{\circledR}$ and Ethical Approval}

The ethical approval had been granted for this thesis by Coventry University ethics department. However, copyright is owned by the author of the thesis. A copy is permitted to be downloaded only for research purposes and private study. The reproducibility of the thesis is prohibited unless permission is granted.

\section{Conflicts of Interest}

The author declares no conflicts of interest regarding the publication of this paper.

\section{References}

[1] Serjeant, G. (2013) The Natural History of Sickle Cell Disease. Cold Spring Harbor Perspectives in Medicine, 3, a011783. https://doi.org/10.1101/cshperspect.a011783

[2] Dormandy, E., James, J., Inusa, B. and Rees, D. (2018) How Many People Have Sickle Cell Disease in the UK? Journal of Public Health, 40, e291-e295. https://doi.org/10.1093/pubmed/fdx172

[3] Adeodu, O., Akinlosotu, M., Adegoke, S. and Oseni, S. (2017) Foetal Haemoglobin and Disease Severity in Nigerian Children with Sickle Cell Anaemia. Mediterranean Journal of Hematology and Infectious Diseases, 9, e2017063. https://doi.org/10.4084/mjhid.2017.063

[4] Islam, N. (2017) Sickle Cell Disease (SCD) A Hidden Genetic Disorder Can Be Treated by Comprehensive Therapy: Research Based Approaches. Scientific Journal of Food Science and Nutrition, 3, 018-022.

[5] Ramachandran, P., Perisetti, A., Kathirvelu, B., Gajendran, M., Ghanta, S., Onukogu, I., Lao, T. and Anwer, F. (2020) Low Morbidity and Mortality with COVID-19 in Sickle Cell Disease: A Single Center Experience. eJHaem, 1, 608-614. https://doi.org/10.1002/jha2.87

[6] Guarda, C., Yahoue, S., Santiago, R., Neres, J., Fernandes, C., Aleluia, M., Figueiredo, C., Fiuza, L., Carvalho, S., Oliveira, R., Fonseca, C., Ndidi, U., Nascimento, V. and Goncalves, L. (2020) Sickle Cell Disease: A Distinction of Two Most Frequent Genotypes (HbSS and HbSC). PLoS ONE, 15, e0228399. 
https://doi.org/10.1371/journal.pone.0228399

[7] Reeves, S., Jary, H., Gondhi, J., Kleyn, M., Bagdady, S. and Dombkowski, K. (2019) Incidence, Demographic Characteristics, and Geographic Distribution of Sickle Cell Trait and Sickle Cell Anemia Births in Michigan, 1997-2014. Molecular Genetics \& Genomic Medicine, 7, e795. https://doi.org/10.1002/mgg3.795

[8] Ware, R., Montalembert, M., Tshilo, L. and Abboud, M. (2017) Sickle Cell Disease. The Lancet, 390, 311-323. https://doi.org/10.1016/S0140-6736(17)30193-9

[9] Ambrose, E., Smart, L., Charles, M., Hernandez, A., Latham, T., Hokoro, A., Beyanga, M., Howard, T., Kanugisha, E., McElhinney, K., Tebuka, E. and Ware, R. (2020) Surveillance for Sickle Cell Disease, United Republic of Tanzania. Bulletin of the World Health Organization, 98, 859-868. https://doi.org/10.2471/BLT.20.253583

[10] Darshana, T., Bandara, D., Nawarathe, U., Silva, U., Costa, Y., Pushpakumara, K., Pathirage, S., Basnayake, S., Epa, C., Dilrukshi, P., Wijayawardena, M., Anthony, A., Rodrigo, R., Manamperi, A., Smith, F., Allen, A., Menxel, S., Rees, D. and Premawardhena, A. (2020) Sickle Cell Disease in Sri Lanka: Clinical and Molecular Basis and the Unanswered Questions about Disease Severity. Orphanet Journal of Rare Diseases, 15, Article No. 177. https://doi.org/10.1186/s13023-020-01458-w

[11] Makani, J., Williams, T. and Marsh, K. (2007) Sickle Cell Disease in Africa: Burden and Research Priorities. Annals of Tropical Medicine \& Parasitology, 101, 3-14. https://doi.org/10.1179/136485907X154638

[12] Galadanci, A., Debaun, M. and Galadanci, N. (2019) Neurologic Complications in Children under Five Years with Sickle Cell Disease. Neuroscience Letters, 706, 201-206. https://doi.org/10.1016/j.neulet.2019.04.030

[13] Kwiatkowski, J., Zimmerman, R., Pollock, A., Seto, W., Whitney, K., Shults, J., Chirchir, A. and Frempong, K. (2009) Silent Infarcts in Young Children with Sickle Cell Disease. British Journal of Haematology, 146, 300-305.

https://doi.org/10.1111/j.1365-2141.2009.07753.x

[14] Edwards, T., Scott, J., Munyoki, G., Odera, V., Chengo, E., Bauni, E., Kwasa, T., Sanderm J., Neville, B. and Newton, C. (2008) Heterogeneity of Prevalence and Risk Factors for Active Convulsive Epilepsy in a Rural District of Kenya. The Lancet Neurology, 7, 50-56. https://doi.org/10.1016/S1474-4422(07)70292-2

[15] Nakamura, Y., Sugino, M., Tsukahara, A., Nakazawa, H., Yamamoto, N. and Arawaka, S. (2018) Posterior Reversible Encephalopathy Syndrome with Extensive Cytotoxic Edema after Blood Transfusion: A Case Report and Literature Review. BMC Neurology, 18, Article No. 190. https://doi.org/10.1186/s12883-018-1194-1

[16] Bellas, S. and Lusardi, M. (2005) Hospital Readmission for Adult Acute Sickle Cell Painful Episodes: Frequency, Etiology, and Prognostic Significance. American Journal of Hematology, 79, 17-25. https://doi.org/10.1002/ajh.20336

[17] Chandegara, V. and Varshney, A. (2012) Aloe vera: Development of Gel Extraction Process for Aloe vera Leaves. Lambert Academic Publication, Saarbrücken.

[18] Nwaoguikpe, R., Ujowundu, C. and Okwu, G. (2013) The Antisickling Potentials of Four Curcubits (T. Occidentalis, C. Maxima; C. Sativus and C. Lonatus). Scholars Journal of Applied Medical Sciences (SJAMS), 1, 191-198.

[19] Okerenta, B., Essien, E. and Esin, J. (2019) Anti-Sickling Properties of Aqueous Extracts of Dennettia tripetala and Physalis angulata. Asian Journal of Biological Sciences, 12, 772-778. https://doi.org/10.3923/ajbs.2019.772.778

[20] Andrea, B., Dumitrita, R., Florina, C., Francisc, D., Anastasia, V., Socaci, S. and Adela, P. (2020) Comparative Analysis of Some Bioactive Compounds in Leaves of Different Aloe Species. BMC Chemistry, 14, Article No. 67. 
https://doi.org/10.1186/s13065-020-00720-3

[21] Nwaoguikpe, R., Braide, W. and Ezejiofor, N. (2010) The Effect of Aloe vera Plant (Aloe barbadensis) Extracts on Sickle Cell Blood (HbSS). African Journal of Food Science and Technology, 1, 58-63.

[22] Langmead, L., Makins, D. and Rampton, S. (2004) Anti-Inflammatory Effects of Aloe vera Gel in Human Colorectal Mucosa in Vitro. Alimentary Pharmacology \& Therapeutics, 19, 521-527. https://doi.org/10.1111/j.1365-2036.2004.01874.x

[23] Lima, A., Santos, P., Verissimo, E., Rebelo, P. and Ferreira, R. (2020) Differential Inhibition of Gelatinase Activity in Human Colon Adenocarcinoma Cells by Aloe vera and Aloe arborescens Extracts. BMC Complementary Medicine and Therapies, 20, Article No. 379. https://doi.org/10.1186/s12906-020-03134-9

[24] Page, M., McKenzie, J., Bossuyt, P., Bourton, I., Hoffmann, T., Mulrow, C., Shamseer, L., Tetzlafff, J. and Moher, D. (2021) Updating Guidance for Reporting Systematic Reviews: Development of the PRISMA 2020 Statement. Journal of Clinical Epidemiology, 1, 1-35. https://doi.org/10.31222/osf.io/jb4dx

[25] Verhagen, A. and Ferreira, M. (2014) Forest Plots. Journal of Physiotherapy, 60, 170-173. https://doi.org/10.1016/j.jphys.2014.06.021

[26] Prel, J., Rohrig, B. and Blettner, M. (2009) Critical Appraisal of Scientific Articles. Deutsches Ärzteblatt International, 106, 100-105.

https://doi.org/10.3238/arztebl.2009.0100

[27] Mpiana, P.T., Ngbolua, K.N., Mudogo, V., Tshibangu, D.S.T., Atibu, E.K., Tshilanda, D.D. and Misengabu, N.M. (2011) Anti-Sickle Erythrocytes Haemolysis Properties and Inhibitory Effect of Anthocyanins Extract of Trema orientalis (Ulmaceae) on the Aggregation of Human Deoxyhemoglobin S in Vivo. Journal of Medical Sciences, 11, 129-137. https://doi.org/10.3923/jms.2011.129.137

[28] Dowdy, A., Tincani, M. and Schneider, W.J. (2020) Evaluation of Publication Bias in Response Interruption and Redirection: A Meta-Analysis. Journal of Applied Behavior Analysis, 53, 2151-2171. https://doi.org/10.1002/jaba.724

[29] Dowdy, A., Tincani, M. and Scheneider, W. (2020) Evaluation of Publication Bias in Response Interruption and Redirection: A Meta-Analysis. Journal of Applied Behaviour Analysis, 53, 2151-2171. https://doi.org/10.1002/jaba.724

[30] Champers, C., Gross, J., Pratt, K., Guo, X., Byrnes, C., Lee, T., Lavelle, D., Dean, A., Miller, J. and Wilber, A. (2020) The mRNA-Binding Protein IGF2BP1 Restores Fetal Hemoglobin in Cultured Erythroid Cells from Patients with $\beta$-Hemoglobin Disorders. Molecular Therapy, Methods \& Clinical Development, 17, 429-440. https://doi.org/10.1016/j.omtm.2020.01.011

[31] DeBaun, M., Jordan, L., King, A., Schatz, J., Vichinsky, E., Fox, C., McKinstry, R., Telfer, P., Kraut, M., Daraz, L., Kirkham, F. and Murad, M. (2020) American Society of Hematology 2020 Guidelines for Sickle Cell Disease: Prevention, Diagnosis, and Treatment of Cerebrovascular Disease in Children and Adults. The American Society of Hematology, 4, 1554-1588.

https://doi.org/10.1182/bloodadvances.2019001142

[32] Shah, N., Bhor, M., Xie, L., Paulose, J. and Yuce, H. (2019) Sickle Cell Disease Complications: Prevalence and Resource Utilization. PLOS ONE, 7, e0214355. https://doi.org/10.1371/journal.pone.0214355

[33] Hazzazi, A., Ageeli, M., Alfaqih, A., Jaafari, A., Malhan, H. and Bakkar, M. (2020) Epidemiology and Characteristics of Sickle Cell Patients Admitted to Hospitals in Jazan Region, Saudi Arabia. Journal of Applied Hematology, 11, 10-14. https://doi.org/10.4103/joah.joah_67_19 
[34] Warghade, S., Britto, J., Haryan, R., Dalvi, T., Bendre, R., Chheda, P., Metkar, S., Salunkhe, Y., Chanekar, M. and Shah, N. (2018) Prevalence of Hemoglobin Variants and Hemoglobinopathies Using Cation-Exchange HPLC in Central Reference Laboratory of India: A Report of 65779 Cases. Journal of Laboratory Physicians, 10, 73-79. https://doi.org/10.4103/JLP.JLP_57_17

[35] Weatherall, D.J. (2010) Thalassemia as a Global Health Problem: Recent Progress toward Its Control in the Developing Countries. Annals of the New York Academy of Sciences, 1202, 17-23. https://doi.org/10.1111/j.1749-6632.2010.05546.x

[36] Piel, B., Patil, A., Howes, R., Nyangiri, O., Gething, P., Williams, T., Weatherall, D. and Hay, S. (2010) Global Distribution of the Sickle Cell Gene and Geographical Confirmation of the Malaria Hypothesis. Nature Communications, 1, Article No. 104. https://doi.org/10.1038/ncomms1104

[37] May, J., Evans, J., Timmann, C., Ehman, C., Busch, W., Thye, T., Agbenyega, T. and Horstmann, R. (2007) Hemoglobin Variants and Disease Manifestations in Severe Falciparum Malaria. JAMA, 297, 2220-2226. https://doi.org/10.1001/jama.297.20.2220

[38] Kelly, S., Jacobs, E., Stone, M., Keating, S., Lee, H., Chafets, D., Heitman, J., Dimapasoc, M., Operskalski, E., Hagar, W., Vichinsky, E., Busch, M., Norris, P. and Custer, B. (2020) Influence of Sickle Cell Disease on Susceptibility to HIV Infection. PLoS ONE, 15, e0218880. https://doi.org/10.1371/journal.pone.0218880

[39] Hay, S., Guerra, C., Gething, P., Patil, A., Tatem, A., Noor, A., Kabaria, C., Manh, B., Elyazar, I., Brooker, Smith, D., Moyeed, R. and Snow, R. (2009) A Worlds Malaria Map: Plasmodium falciparum Endemicity in 2007. PLoS Medicine, 6, e1000048. https://doi.org/10.1371/journal.pmed.1000048

[40] Ravenhall, M., Campino, S., Sepulveda, N., Manjurano, A., Nadjm, B., Mtove, G., Wangai, H., Maxwell, C., Olomi, R., Reyburn, H., Drakeley, C., Riley, E. and Clark, T. (2018) Novel Genetic Polymorphisms Associated with Severe Malaria and under Selective Pressure in North-Eastern Tanzania. PLoS Genetics, 14, e1007172. https://doi.org/10.1371/journal.pgen.1007172

[41] Cesar, P., Dhyani, A., Schwade, L., Acordi, P., Albuquerque, C., Nina, R., De Paula, E. and Fraiji, N. (2019) Epidemiological, Clinical, and Severity Characterization of Sickle Cell Disease in a Population from the Brazilian Amazon. Hematology/Oncology and Stem Cell Therapy, 12, 204-210. https://doi.org/10.1016/j.hemonc.2019.04.002

[42] Wambua, S., Mwangi, T., Kortok, M., Uyoga, S., Macharia, A., Mwacharo, J., Weatherall, D., Snow, R., Marsh, K. and Williams, T. (2006) The Effect of $\alpha^{+}$-Thalassaemia on the Incidence of Malaria and Other Diseases in Children Living on the Coast of Kenya. PLoS Medicine, 3, e158. https://doi.org/10.1371/journal.pmed.0030158

[43] Hsiang, M., Ntuku, H., Roberts, K., Dufour, M., Whittemore, B., Tambo, M., McCreesh, P., Medzihradsky, O., Prach, L., Siloka, G., Siame, N., Gureye, C., Schubbe, L., Wu, L., Scott, V., Tesserna, S., Greenhouse, B., Erlank, E., Koekemoer, L., Sturrock, H., Mwilima, A., Katokele, S., Uusiku, P., Bennett, A., Smith, J., Kleischmidt, I., Mumbengegwi, D. and Gosling, R. (2020) Effectiveness of Reactive Focal Mass Drug Administration and Reactive Focal Vector Control to Reduce Malaria Transmission in the Low Malaria-Endemic Setting of Namibia: A Cluster-Randomised Controlled, Open-Label, Two-by-Two Factorial Design Trial. The Lancet, 395, 1361-1373. https://doi.org/10.1016/S0140-6736(20)30470-0

[44] Adjah, J., Fiadzoe, B., Torgby, R. and Amoah, L. (2018) Seasonal Variations in Plasmodium falciparum Genetic Diversity and Multiplicity of Infection in Asymptomatic Children Living in Southern Ghana. BMC Infectious Diseases, 432, Article No. 432. https://doi.org/10.1186/s12879-018-3350-z 
[45] Metoh, T., Chen, J., Gah, P., Zhou, X., Somo, R. and Zhou, X. (2020) Genetic Diversity of Plasmodium falciparum and Genetic Profile in Children Affected by Uncomplicated Malaria in Cameroon. Malaria Journal, 19, Article No. 115. https://doi.org/10.1186/s12936-020-03161-4

[46] Padilla-Rodriguez, J., Olivera, M. and Garcia, B. (2020) Parasite Density in Severe Malaria in Colombia. PLoS Medicine, 15, e0235119.

https://doi.org/10.1371/journal.pone.0235119

[47] Penman, B., Pybus, O., Weatherall, D. and Gupta, S. (2009) Epistatic Interactions between Genetic Disorders of Hemoglobin Can Explain Why the Sickle-Cell Gene Is Uncommon in the Mediterranean. Proceedings of the National Academy of Sciences of the United States of America, 106, 21242-21246.

https://doi.org/10.1073/pnas.0910840106

[48] Gordeuk, V., Shah, B., Zhang, X., Thuma, P., Zulu, S., Moono, R., Reading, S., Song, J., Zhang, Y., Nouraie, M., Campbell, A., Minitti, C., Rana, S., Darbari, D., Kato, G., Niu, M., Castro, O., Machado, R., Gladwin, M. and Prchal, J. (2020) The CYB5R3 ${ }^{\text {c.350C }>\text { G }}$ and G6PD A Alleles Modify Severity of Anemia in Malaria and Sickle Cell Disease. American Journal of Hematology, 95, 1269-1279. https://doi.org/10.1002/ajh.25941

[49] Tusting, L., Rek, J., Arinaitwe, E., Staedke, S., Kamya, M., Cano, J., Bottomley, C., Johnston, D., Dorsey, G., Lindsay, S. and Lines, J. (2016) Why Is Malaria Associated with Poverty? Findings from a Cohort Study in Rural Uganda. Infectious Diseases of Poverty, 5, Article No. 78. https://doi.org/10.1186/s40249-016-0164-3

[50] Bao, E., Lareau, C., Brugnara, C., Fulcher, I., Barau, C., Mountereau, S., Habibi, A., Babaoui, B., Berkenou, J., Bartolucci, P., Galacteros, F., Platt, O., Mahaney, M. and Sankaran, V. (2019) Heritability of Fetal Hemoglobin, White Cell Count, and Other Clinical Traits from a Sickle Cell Disease Family Cohort. American Journal of Hematology, 94, 522-527. https://doi.org/10.1002/ajh.25421

[51] Adeodu, O., Akinlosotu, M., Adegoke, S. and Oseni, S. (2017) Foetal Haemoglobin and Disease Severity in Nigerian Children with Sickle Cell Anaemia' Mediterranean. Journal of Hematology and Infectious Diseases, 9, e2017063. https://doi.org/10.4084/mjhid.2017.063

[52] Lobitz, S., Klein, J., Brose, A., Blankenstein, O. and Frommel, C. (2019) Newborn Screening by Tandem Mass Spectrometry Confirms the High Prevalence of Sickle Cell Disease among German Newborns. Annals of Hematology, 98, 47-53. https://doi.org/10.1007/s00277-018-3477-4

[53] Ceglie, G., Mauro, M., Jacobis, I., Gennaro, F., Quaranta, M., Baronci, C., Villani, A. and Palumbo, G. (2019) Gender-Related Differences in Sickle Cell Disease in a Pediatric Cohort: A Single-Center Retrospective Study. Frontiers in Molecular Biosciences, 6, 140. https://doi.org/10.3389/fmolb.2019.00140

[54] Heymann, L., Dubert, M., Diallo, D., Diop, S., Tolo, A., Belinga, S., Ibrahima, S., Diagne, I., Wamba, G., Boidy, K., Ly, I., Kamara, I., Traore, Y., Offredo, L., Jouven, X. and Ranque, B. (2018) Prevalence and Correlates of Growth Failure in Young African Patients with Sickle Cell Disease. British Journal of Haematology, 184, 253-262. https://doi.org/10.1111/bjh.15638

[55] Owusu, E., Cofie, N., Nai, E., Grobusch, K., Brown, C., Mens, P. and Grobusch, M. (2018) Malaria, Sickle Cell Disease, HIV, and Co-Trimoxazole Prophylaxis: An Observational Study. International Journal of Infectious Diseases, 69, 29-34. https://doi.org/10.1016/j.ijid.2018.01.031

[56] Dapar, M., Meve, U., Schumann, S. and Alejandro, G. (2020) Ethnomedicinal Appraisal and Conservation Status of Medicinal Plants among the Manobo Tribe of Bayugan City, Philippines. Biodiversitas Journal of Biological Diversity, 21, 3843-3855. 
https://doi.org/10.13057/biodiv/d210854

[57] De-la-Cruz, H., Vilcapoma, G. and Zevallos, P. (2007) Ethnobotanical Study of Medicinal Plants Used by the Andean People of Canta, Lima, Peru. Journal of Ethnopharmacology, 111, 284-294. https://doi.org/10.1016/j.jep.2006.11.018

[58] John, C., Opoka, R., Latham, T., Hume, H., Nabaggala, C., Kasirye, P., Ndugwa, C., Lane, A. and Ware, R. (2020) Hydroxyurea Dose Escalation for Sickle Cell Anemia in Sub-Saharan Africa. The New England Journal of Medicine, 382, 2524-2533. https://doi.org/10.1056/NEJMoa2000146

[59] Rai, P. and Ataga, K. (2020) Drug Therapies for the Management of Sickle Cell Disease [Version 1; Peer Review: 1 Approved]. F1000Research, 9, 592.

https://doi.org/10.12688/f1000research.22433.1

[60] Munyangi, J., Vernet, L., Idumbo, M., Lu, C., Perronne, C., Ngombe, N., Bianga, J., Mupenda, B., Mergeai, G., Mumba, D., Towler, M. and Weathers, P. (2019) RETRACTED: Artemisia annua and Artemisia afra Tea Infusions vs. Artesunate-Amodiaquine (ASAQ) in Treating Plasmodium falciparum Malaria in a Large Scale, Double Blind, Randomized Clinical Trial. Phytomedicine, 57, 49-56. https://doi.org/10.1016/j.phymed.2018.12.002

[61] Dash, B., Archana, Y., Satapathy, N. and Naik, S. (2013) Search for Antisickling Agents from Plants. Pharmacognosy Reviews, 7, 53-60. https://doi.org/10.4103/0973-7847.112849

[62] Waruruai, J., Sipana, B., Koch, M., Barrows, L., Matainaho, T. and Rai, P. (2011) An Ethnobotanical Survey of Medicinal Plants Used in the Siwai and Buin Districts of the Autonomous Region of Bougainville. Journal of Ethnopharmacology, 138, 564-577. https://doi.org/10.1016/j.jep.2011.09.052

[63] Mushtaq, S., Mushtaq, Z., Arif, J., Fatima, M., Bahawal, S., Ain, Q. and Chirahg, S. (2020) Comparison of Effect of Aloe vera Gel with Aspirin and Celecoxib on Platelet Aggregation. The Professional Medical Journal, 27, 973-978. https://doi.org/10.29309/TPMJ/2020.27.05.4007

[64] Kitadi, J., Mazasa, P., Tshibangu, D., Kasali, F., Tshilanda, D., Mushagalusa, F., Ngbolua, K. and Mpiana, P. (2020) Ethnopharmacological Survey and Antisickling Activity of Plants Used in the Management of Sickle Cell Disease in Kikwit City, DR Congo. Evidence-Based Complementary and Alternative Medicine, 2020, Article ID 1346493. https://doi.org/10.1155/2020/1346493

[65] Ilagouma, A., Amadou, I., Isaaka, H., Ilagouma, O. and Ikhiri, K. (2019) Preliminary Study to Identify Anti-Sickle Cell Plants in Niger's Traditional Pharmacopoeia and Their Phytochemicals. Journal of Medicinal Plants Research, 13, 509-517. https://doi.org/10.5897/JMPR2019.6834

[66] Uwakwe, A. and Nwaoguikpe, R. (2008) In Vitro Antisickling Effects of Xylopia aethiopica and Monodora myristica. Journal of Medicinal Plants Research, 2, 119-124.

[67] Eaton, W. and Bunn, F. (2017) Treating Sickle Cell Disease by Targeting HbS Polymerization. Blood, 129, 2719-2726. https://doi.org/10.1182/blood-2017-02-765891

[68] Vekilov, P. (2007) Sickle-Cell Haemoglobin Polymerization: Is It the Primary Pathogenic Event of Sickle-Cell Anaemia? British Journal of Haematology, 139, 173-184. https://doi.org/10.1111/j.1365-2141.2007.06794.x

[69] Haan, K., Koydemir, H., Rivenson, Y., Tseng, D., Dyne, E., Balic, L., Liang, K., Ilango, M., Gumustekin, E. and Ozcan, A. (2020) Automated Screening of Sickle Cells Using a Smartphone-Based Microscope and Deep Learning. npj Digital Medicine, 3, Article No. 76. https://doi.org/10.1038/s41746-020-0282-y

[70] Nwaoguikpe, R. and Uwakwe, A. (2005) The Antisickling Effects of Dried Fish (Ti- 
lapia) and Dried Prawn (Astacus red). Journal of Applied Sciences and Environmental Management, 9, 115-119. https://doi.org/10.4314/jasem.v9i3.17364

[71] Nwaoguikpe, R.N., Braide, W. and Ezejiofor, T.I.N. (2010) The Effect of Aloe Vera Plant (Aloe barbadensis) Extracts on Sickle Cell Blood (Hbss). African Journal of Food Science and Technology, 1, 58-63.

[72] Rauha, J., Remes, S., Heinonen, M., Hopia, A., Kahkonen, M., Kujala, T., Pihlaja, K., Vuorela, H. and Vuorela, P. (2000) Antimicrobial Effects of Finnish Plant Extracts Containing Flavonoids and Other Phenolic Compounds. International Journal of Food Microbiology, 56, 3-12. https://doi.org/10.1016/S0168-1605(00)00218-X

[73] Ataga, K., Kutlar, A., Kanter, J., Liles, D., Cancado, R., Friedrisch, J., Guthrie, T., Madden, J., Alvarez, O., Gordeuk, V., Gualando, S., Colella, M., Smith, W., Rollins, S., Stocker, J. and Rother, R. (2017) Crizanlizumab for the Prevention of Pain Crises in Sickle Cell Disease. The New England Journal of Medicine, 376, 429-439. https://doi.org/10.1056/NEJMoa1611770

[74] Zhang, J., Gong, N., Huang, J., Guo, L. and Wang, Y. (2013) Gelsemine, a Principal Alkaloid from Gelsemium sempervirens Ait., Exhibits Potent and Specific Antinociception in Chronic Pain by Acting at Spinal a3 Glycine Receptors. Pain, 154, 2452-2462. https://doi.org/10.1016/j.pain.2013.07.027

[75] Zagriadskii, E., Bogomazov, A. and Golovko, E. (2018) Conservative Treatment of Hemorrhoids: Results of an Observational Multicenter Study. Advances in Therapy, 35, 1979-1992. https://doi.org/10.1007/s12325-018-0794-X

[76] Russo, M., Coppola, V., Giannetti, E., Buonolonta, R., Piscitelli, A. and Staiano, A. (2018) Oral Administration of Tannins and Flavonoids in Children with Acute Diarrhea: A Pilot, Randomized, Control-Case Study. Italian Journal of Pediatrics, 44, Article No. 64. https://doi.org/10.1186/s13052-018-0497-6

[77] Wanjohi, B., Sudoi, V., Njenga, E. and Kipkore, W. (2020) An Ethnobotanical Study of Traditional Knowledge and Uses of Medicinal Wild Plants among the Marakwet Community in Kenya. Evidence-Based Complementary and Alternative Medicine, 2020, Article ID: 3208634. https://doi.org/10.1155/2020/3208634

[78] Kisielius, V., Hama, J., Skribic, N., Hansen, H., Strobel, B. and Rasmussen, L. (2020) The Invasive Butterbur Contaminates Stream and Seepage Water in Groundwater Wells with Toxic Pyrrolizidine Alkaloids. Scientific Reports, 10, Article No. 19784. https://doi.org/10.1038/s41598-020-76586-1

[79] Bernstein, N., Akram, M., Bachrach, Z. and Daniyal, M. (2021) Is It Safe to Consume Traditional Medicinal Plants during Pregnancy? Phytotherapy Research, 35, 1908-1924. https://doi.org/10.1002/ptr.6935

[80] Cuzzolin, L., Pesenti, F., Verlato, G., Joppi, M., Baldelli, P. and Benoni, G. (2010) Use of Herbal Products among 392 Italian Pregnant Women: Focus on Pregnancy Outcome. Pharmacoepidemiology and Drug Safety, 19, 1151-1158. https://doi.org/10.1002/pds.2040

[81] Samavati, R., Ducza, E., Toth, J. and Gaspar, R. (2017) Herbal Laxatives and Antiemetics in Pregnancy. Reproductive Toxicology, 72, 153-158.

https://doi.org/10.1016/j.reprotox.2017.06.041

[82] Drabek, M., Piekut, A., Szymala, I., Oleksiuk, K., Razzaghi, M., Osmala, W., Jablonska, K. and Dziubanek, G. (2020) Health Risks from Consumption of Medicinal Plant Dietary Supplements. Food Science and Nutrition, 8, 3535-3544. https://doi.org/10.1002/fsn3.1636

[83] Aanouz, I., Belhassan, A., El-Khatabi, K., Lakhilifi, T., El-Idrissi, M. and Bouachrine, M. (2021) Moroccan Medicinal Plants as Inhibitors against SARS-CoV-2 Main Pro- 
tease: Computational Investigations. Journal of Biomolecular Structure and Dynamics, 39, 2971-2979. https://doi.org/10.1080/07391102.2020.1758790

[84] Divya, M., Vijaykumar, S., Chen, J., Vaseeharam, B. and Lara, E. (2020) South Indian Medicinal Plants Can Combat Deadly Viruses along with COVID-19?-A Review. Microbial Pathogenesis, 148, e104277. https://doi.org/10.1016/j.micpath.2020.104277

[85] Reiss, M., Han, Y., Garcia, E., Goldberg, M., Yu, H. and Garner, W. (2010) Matrix Metalloproteinase-9 Delays Wound Healing in a Murine Wound Model. Surgery, 147, 295-302. https://doi.org/10.1016/j.surg.2009.10.016 


\section{Abbreviations}

$\begin{array}{cc}\text { ALE } & \text { Acidic Metabolite } \\ \text { BLE } & \text { Basic Metabolite } \\ \text { BM } & \text { Botanical Medicine } \\ \text { BUS } & \text { Butanol solution } \\ \text { CAE } & \text { Crude Aqueous Extract } \\ \text { CI } & \text { Confidence Interval } \\ \text { Conc. } & \text { Concentration } \\ \text { EtOH } & \text { Ethanolic } \\ \text { FAS } & \text { Fat Soluble } \\ \text { GSH } & \text { Glutathione Peroxidase } \\ \text { Hb } & \text { Haemoglobin } \\ \text { HbF } & \text { Foetal Haemoglobin } \\ \text { HbS } & \text { Sickle Haemoglobin } \\ \text { IR } & \text { Intra Red (analysis) } \\ \text { LE } & \text { Leaf Extract }\end{array}$

MPPIs

MV

MWS

NLE

PRISMA

RBCs

ROS

SCA

SCD

SCs

$\mathrm{SD}$

SOD

TLC

WAS
Metalloproteinase Inhibitors

$$
\text { Mean Value }
$$

Methanol Water Soluble

Neutral Metabolite

Preferred Reporting Items for Systematic Review Red Blood Cells/Erythrocytes (synonym) Reactive Oxygen Species Sickle Cell Anaemia Sickle Cell Disease Sickle cells/Drepanocytes (synonym)

Standard Deviation

Superoxide Dismutase

Thin Layer Chromatography (Procedure) 